\title{
PENERAPAN PRINSIP MENGENAL NASABAH PADA BANK PERKREDITAN RAKYAT BERDASARKAN PBI NOMOR 12/20/PBI/2010
}

Nurfitriyani

\author{
Mahasiswa Magister Ilmu Hukum, Fakultas Hukum, Universitas Brawijaya
}

vivienfitriani@gmail.com

Submitted: 2020-11-26 | Reviewed: 2021-03-01 | Accepted: 2021-04-13

How to cite: Nurfitriyani. "Penerapan Prinsip Mengenal Nasabah pada Bank Perkreditan Rakyat Berdasarkan PBI Nomor 12/20/PBI/2010". Dialogia Iuridica: Jurnal Hukum Bisnis dan Investasi, Vol. 12, No. 2, (2021): 036049.

\section{DOI:}

https://doi.org/10.28932/di.v12i2.3148

\section{ABSTRACT}

With the development of the People's Credit Bank industry with the development of People's Credit Bank products and services, especially those based on information technology, the risk of using Rural Banks in money laundering and terrorism financing is getting higher. The provisions concerning the Application of Know Your Customer Principles for Rural Banks need to be revised by referring to general principles that apply internationally in supporting efforts to prevent money laundering and prevent terrorism financing. so that the authors are interested in conducting research with the title: Application of Know Your Customer Principles at Rural Banks Based on Bank Indonesia Regulation Number 12/20 / PBI / 2010. The creation of this journal is expected to provide an integral understanding of scientific concepts regarding the Application of Know Your Customer Principles at Rural Banks and contribute to ideas in the field of law in general and in particular in the field of banking law related to the application of the principle of knowing the customers of rural credit banks based on Bank Indonesia Regulation Number 12. / 20 / PBI / 2010. The 
method used in writing this journal is a normative research method with literature study through books, journal references, and laws and regulations that are relevant to the issues examined in the journal. The results of this study indicate that the application of Know Your Customer Principles for Rural Banks is an effort to support the prevention of money laundering and the prevention of terrorism financing. Therefore, Rural Banks are required to implement the Anti Money Laundering and Terrorism Funding Prevention Program.

Keywords: Customers; Indonesian Bank Regulations; Rural Banks.

\section{PENDAHULUAN}

Perbankan merupakan sasaran pembangunan ekonomi, di mana perbankan diharapkan mampu mengembangkan dan memajukan perekonomian di Indonesia. Khususnya dalam meningkatkan pemerataan kesejahteraan rakyat banyak, dalam hal ini bukan kesejahteraan segolongan orang atau perorangan saja melainkan kesejahteraan seluruh rakyat Indonesia tanpa terkecuali. Dalam hal ini menandakan bahwa bank sangatlah penting dalam pembangunan nasional karena fungsi Bank dalam UU Republik Indonesia No.10 Tahun 1998 tentang Perubahan Atas UU No.7 Tahun 1992 tentang Perbankan Pasal 1 angka (2) mendifinisikan fungsi Bank adalah badan usaha yang menghimpun dana dari masyarakat dalam bentuk simpanan dan menyalurkannya kepada masyarakat dalam bentuk kredit dan atau bentuk-bentuk lainnya dalam rangka meningkatkan taraf hidup rakyat banyak.

Di Indonesia, prinsip mengenal nasabah pertama kali diatur dalam Peraturan Bank Indonesia (PBI) No. 3/10/PBI/2001 tentang Penerapan Prinsip Mengenal Nasabah (Know Your Customer Principles) sebagaimana terakhir diubah dengan PBI No. 5/21/PBI/2003. Yang dimaksud dengan Prinsip Mengenal Nasabah dalam PBI ini adalah "prinsip yang diterapkan bank untuk mengetahui identitas nasabah, memantau kegiatan transaksi nasabah termasuk pelaporan transaksi yang mencurigakan". Adapun yang dimaksud dengan transaksi yang mencurigakan adalah:

1. Transaksi keuangan yang menyimpang dari profil, karakterisitik, atau kebiasaan pola transaksi dari nasabah yang bersangkutan;

2. Transaksi keuangan oleh nasabah yang patut diduga dilakukan dengan tujuan untuk menghindari pelaporan transaksi yang bersangkutan yang wajib dilakukan oleh bank sesuai dengan ketentuan dalam Undang-undang Nomor 15 Tahun 2002 tentang Tindak Pidana Pencucian Uang sebagaimana telah diubah dengan Undang-undang Nomor 25 Tahun 2003; atau 
Volume 12, Nomor 2, April 2021

3. Transaksi keuangan yang dilakukan atau batal dilakukan dengan menggunakan harta kekayaan yang diduga berasal dari hasil tindak pidana.

Berdasarkan ketentuan di atas dapat dipahami bahwa melalui penerapan prinsip mengenal nasabah diharapkan bank secara dini dapat mengidentifikasi transaksi yang mencurigakan, untuk meminalisir berbagai risiko, seperti risiko operasional (operasional risk), risiko hukum (legal risk), risiko terkonsentrasinya transaksi (concentration risk), dan risiko reputasi (reputational risk). Di samping itu, dengan menerapkan prinsip ini, bank diharapkan tidak hanya mengenal nasabah secara harfiah saja, tapi bisa mengenal lebih konfrehensif lagi, tidak hanya mengetahui identitas nasabah tapi juga berkaitan dengan profil dan karakter transaksi nasabah, yang dilakukan melalui jasa perbankan. ${ }^{1}$

Terkait dengan pembahasahan di atas, pada tahun 2009, PBI No. 5/21/PBI/2003 tentang Penerapan Mengenal Nasabah (Know Your Customer Principles), disempurnakan dengan PBI No. 11/28/PBI/2009 tentang Penerapan Program Anti Pencucian Uang dan Pencegahan Pendanaan Terorisme Bagi Bank Umum, yang diperbahuri dengan PBI No. 14/27/PBI/2012. PBI ini mengadopsi rekomendasi yang dikeluarkan oleh Financial Action Task Force (FATF) terkait dengan upaya pencegahan tindak pidana pencucian uang dan pencegahan pendanaan terorisme dengan menggunakan fasilitas dan produk perbankan. Menariknya, dalam Peraturan ini, terminologi know your customer diubah dengan terminologi customer due diligence (CDD). Yang dimaksud dengan CDD adalah 'kegiatan berupa identifikasi, verifikasi, dan pemantauan yang dilakukan Bank untuk memastikan bahwa transaksi tersebut sesuai dengan profil calon nasabah, WIC (walk in customer), atau nasabah. Di samping terminologi CDD, terdapat juga terminologi enhanced due diligence (EDD). EDD adalah 'tindakan CDD lebih mendalam yang dilakukan Bank pada saat berhubungan dengan calon nasabah, WIC, atau nasabah yang tergolong berisiko tinggi, termasuk politically exposed person, terhadap kemungkinan pencucian uang dan pendanaan terorisme."

Berdasarkan penjelasan di atas dapat dipahami bahwa penerapan prinsip mengenal nasabah (know your customer principle) sangat penting dalam industri perbankan guna menjaga stabilitas kesehatan bank. Seiring dengan perkembangan teknologi dan informasi, semakin kompleksnya produk dan aktivitias perbankan, maka risiko yang dihadapi oleh bank juga akan semakin meningkat. Peningkatan risiko ini mesti diimbangi dengan peningkatan kualitas manajemen risiko. Pengaturan penerapan prinsip mengenal nasabah juga disempurnakan berdasarkan standar internasional dengan menggunakan istilah baru customer due diligence dan enhanced due diligence. Hal ini mengindikasikan betapa pentingnya penerapan prinsip ini dalam perbankan guna menghindari risiko yang semakin sophisticated yang pada akhirnya diharapkan terwujudnya trust nasabah dan bank yang sehat.

Seiring dengan perkembangan produk, aktivitas dan teknologi informasi bank yang semakin kompleks dikhawatirkan dapat meningkatkan peluang bagi pihak-pihak yang tidak

\footnotetext{
${ }^{1}$ Nindyo Pramono, Bunga Rampai Hukum Bisnis Aktual, Bandung: Citra Aditya Bakti. 2006. hlm. 218-219.
} 
Volume 12, Nomor 2, April 2021

bertanggungjawab untuk menggunakan produk/jasa bank dalam membantu tindak kejahatannya, untuk itu, agar penggunaan bank sebagai sarana pencucian uang dan pendanaan dapat diminimalisir, diperlukan peranan bank yang lebih besar dari sebelumnya yaitu dengan menerapkan program APU dan PPT yang optimal dan efektif. Penerapan program APU dan PPT oleh bank tidak saja penting untuk pemberantasan pencucian uang, melainkan juga untuk mendukung penerapan prudential banking yang dapat melindungi bank dari berbagai risiko yang mungkin timbul antara lain risiko hukum, risiko reputasi, risiko operasional.

BPR (Bank Perkreditan Rakyat) adalah badan usaha yang menghimpun dana dari masyarakat dalam bentuk simpanan dan menyalurkannya kepada masyarakat dalam bentuk kredit atau dalam bentuk lainnya dalam rangka meningkatkan taraf hidup seluruh rakyat. Dalam sistem perbankan di Indonesia Bank Perkreditan Rakyat diberi peran yang penting, yaitu memberikan pelayanan perbankan kepada usaha kecil atau usaha mikro dan sektor informal, terutama di daerah pedesaan. Dengan membantu dalam memberikan pelayanan perbankan khususnya dalam pemberian pinjaman untuk menciptakan pekerjaan mandiri kepada rakyat kecil yang bekerja dalam sektor informal di kota maupun di daerah pedesaan, Bank Perkreditan Rakyat berperan dalam membantu menciptakan lapangan kerja baru, pemerataan kesempatan berusaha dan pemerataan pendapatan.

Semakin berkembangnya industri BPR dan BPRS (Bank Perkreditan Rakyat Syariah) disertai dengan perkembangan produk serta pelayanan BPR/BPRS (Bank Perkreditan Rakyat Syariah) terutama yang berbasis teknologi informasi, maka risiko pemanfaatan BPR dan BPRS dalam pencucian uang dan pendanaan terorisme semakin tinggi.

Ketentuan tentang Penerapan Prinsip Mengenal Nasabah (Know Your Customer Principles/KYC) bagi BPR dan BPRS yang berlaku selama ini perlu untuk disempurnakan dengan mengacu pada prinsip-prinsip umum yang berlaku secara internasional dalam mendukung upaya pencegahan tindak pidana pencucian uang dan pencegahan pendanaan terorisme, sehingga penulis, dalam penulisan Jurnal ini, pokok-pokok permasalahan yang ingin penulis kemukakan adalah Bagaimana Penerapan Prinsip Mengenal Nasabah Pada Bank Perkreditan Rakyat berdasarkan PBI Nomor 12/20/PBI/2010.

Adapun tujuan dari penelitian ini adalah sebagai berikut: 1. Untuk mengetahui penerapan prinsip mengenal nasabah berdasarkan peraturan Bank Indonesia No. 12/20/PBI/2010 tentang Penerapan Program Anti Pencucian Uang dan Pencegahan Pendanaan Terorisme Bagi Bank Perkreditan Rakyat dan Bank Pembiayaan Rakyat Syariah. Kaitanya dengan upaya apa saja yang dilakukan oleh pihak Bank Perkreditan Rakyat dalam mencegah Tindak Pidana Pencucian Uang dalam kaitannya dengan penerapan Prinsip Mengenal Nasabah (Know Your Costumer Principles) Sedangkan kegunaan dari penelitian ini adalah: 1. Segi teoritis/akademis, Menambah wawasan penulis secara umum dan memberikan kontribusi terhadap perkembangan ilmu hukum dalam bidang perbankan khususnya. 2. Segi praktis, Sebagai bahan masukan, pertimbangan dan sumbangan pemikiran bagi pihak-pihak yang terkait dengan penulisan ini. 


\section{PEMBAHASAN}

\section{Pengertian dan Penerapan Prinsip Mengenal Nasabah}

Nasabah itu ibarat nafas yang sangat berpengaruh terhadap kelanjutan suatu bank. Oleh karena itu bank harus dapat menarik nasabah sebanyak-banyaknya agar dana yang terkumpul dari nasabah tersebut dapat diputar oleh bank yang nantinya disalurkan kembali. Menurut Djaslim Saladin dalam bukunya: "Dasar-Dasar Manajemen Pemasaran Bank" yang dikutip dari "Kamus Perbankan" menyatakan bahwa "Nasabah adalah orang atau badan yang mempunyai rekening simpanan atau pinjaman. Sedangkan menurut Komaruddin ${ }^{3}$ dalam Kamus Perbankan: menyatakan bahwa "Nasabah adalah seseorang atau suatu perusahaan yang mempunyai rekening koran atau deposito atau tabungan serupa lainnya pada sebuah bank".

Definisi nasabah baru dapat direalisasikan dalam Undang-Undang Nomor 10 Tahun 1998 tentang Perubahan Atas Undang-Undang Nomor 7 Tahun 1992 tentang Perbankan diatur perihal nasabah yang terdiri dari dua pengertian yaitu:

1. Nasabah penyimpan adalah nasabah yang menempatkan dananya di bank dalam bentuk simpanan berdasarkan perjanjian bank dengan nasabah yang bersangkutan.

2. Nasabah debitur adalah nasabah yang memperoleh fasilitas kredit atau pembiayaan berdasarkan prinsip syariah atau yang dipersamakan dengan itu berdasarkan perjanjian bank dengan nasabah yang bersangkutan.

Sementara itu Undang-Undang Nomor 24 Tahun 2004 tentang Lembaga Penjamin Simpanan mengenal pengertian nasabah sebagaimana dijelaskan dalam Undang-Undang Nomor 10 Tahun 1998 tentang Perubahan Atas Undang-Undang Nomor 7 Tahun 1992 tentang Perbankan, yaitu:

1. Pengertian Nasabah penyimpan, yaitu nasabah yang menempatkan dananya di bank dalam bentuk simpanan berdasarkan perjanjian bank dengan nasabah yang bersangkutan.

2. Pengertian Nasabah debitur adalah nasabah yang memperoleh fasilitas kredit atau pembiayaan berdasarkan prinsip syariah atau yang dipersamakan dengan itu berdasarkan perjanjian bank dengan nasabah yang bersangkutan.

Kamus besar Bahasa Indonesia menjelaskan nasabah adalah "orang yang biasa berhubungan dengan atau menjadi pelanggan bank (dalam hal keuangan), dapat juga diartikan sebagai orang yang menjadi tanggungan asuransi, perbandingam pertalian. Sedangkan Muhammad Djumhana ${ }^{4}$ menyebutkan nasabah merupakan konsumen dari

\footnotetext{
${ }^{2}$ Djaslim Saladin. Dasar-dasar Manajemen Pemasaran Bank. Jakarta: CV Rajawali. 1994, hlm 84.

${ }^{3}$ Komarudin. Kamus Perbankan. Jakarta: Rajawali. 1994, hlm 102.

${ }^{4}$ Djumhana Muhammad, Hukum Perbankan di Indonesia, Bandung: PT Aditya Bakti. 2006.
} 
Volume 12, Nomor 2, April 2021

pelayanan jasa perbankan. Dari pengertian di atas penulis memberikan kesimpulan bahwa "Nasabah adalah seseorang ataupun badan usaha (korporasi) yang mempunyai rekening simpanan dan pinjaman dan melakukan transaksi simpanan dan pinjaman tersebut pada sebuah bank". Karena nasabah merupakan bagian yang terpenting dalam sebuah bank, maka penting untuk mengenali nasabah, karena prinsip mengenali nasabah merupakan asas atau dasar yang digunakan lembaga perbankan untuk mengetahui segala sesuatu tentang nasabah yang berkaitan dengan penggunaan jasa perbankan.

Prinsip mengenal nasabah merupakan prinsip yang diterapkan bank untuk mengetahui identitas nasabah, memantau kegiatan transaksi nasabah termasuk pelaporan transaksi yang mencurigakan. Prinsip ini mendapat pengaturannya dalam Peraturan Bank Indonesia No 3 Tahun 2001 sebagaimana diubah dengan Peraturan bank Indonesia nomor 5/23/PBI/Tahun 2003 tanggal 23 Oktober 2003. Dalam peraturan tersebut jelas bahwa, prinsip mengenal nasabah merupakan salah satu upaya dalam melaksanakan prinsip kehati-hatian. Prinsip mengenal nasabah ini wajib diterapkan oleh bank, yaitu bank umum sebagaimana dimaksudkan dalam UU Perbankan 1992 sebagaimana telah diubah dengan UU Perbankan 1998. Ketentuan mengenai prinsip mengenal nasabah yang dikeluarkan oleh lembaga pengawas masing masing bank merupakan instrumen yang digunakan oleh bank terhadap nasabahnya. Kewajiban dari bank berkenaan dengan prinsip mengenal nasabah ini dituangkan dalam kebijakan kebijakan bank. Kebijakan kebijakan dimaksud adalah sebagai berikut:

a. Kebijakan penerimaan nasabah;

b. Kebijakan dan prosedur mengidentifikasi nasabah;

c. Kebijakan dan prosedur pemantauan terhadap rekening dan transaksi nasabah;

d. Kebijakan dan prosedur manajemen risiko yang berkaitan dengan prinsip mengenal nasabah. ${ }^{5}$

Sehubungan dengan penerapan prinsip mengenal nasabah dalam industri perbankan ini, Bank Indonesia mengeluarkan Peraturan Bank Indonesia Nomor 3/10/PBI/2001 tentang Penerapan Prinsip Merger, Nasabah (Know Your Customer Principles) sebagaimana telah diubah berturut-turut dengan Peraturan Bank Indonesia Nomor 3/23/PBI/2001 dan Peraturan Bank Indonesia Nomor 5/21/PBI/2003. Khusus bagi Bank Perkreditan Rakyat, Bank Indonesia mengeluarkan ketentuan tersendiri dengan Peraturan Bank Indonesia Nomor 5/23/PBI/2003 tentang Penerapan Prinsip Mengenal Nasabah (Know Your Customer Principles) bagi Bank Perkreditan Rakyat. Kemudian sebagai tindak lanjutnya, Bank Indonesia juga mengeluarkan sejumlah petunjuk pelaksanaan, di antaranya dalam: ${ }^{6}$

\footnotetext{
${ }^{5}$ Asep Rozali, "Prinsip Mengenal Nasabah (Know Your Customer Principle) Dalam Praktik Perbankan”, Jurnal Wawasan Hukum, Vol. 24 No. 01 Februari 2011, hlm 304.

${ }^{6}$ Djoni S. Gazali dan Rachman Usman, Hukum Perbankan, Jakarta: Sinar Grafika, 2012, hlm. 255.
} 
Volume 12, Nomor 2, April 2021

1. Surat Edaran Bank Indonesia Nomor 3/29/DPNP tanggal 13 Desember 2001 perihal Pedoman Standar Penerapan Prinsip Mengenal Nasabah sebagaimana telah diubah dengan Surat Edaran Bank Indonesia Nomor 5/32/DPNP tanggal 4 Desember 2003.

2. Surat Edaran Bank Indonesia Nomor 6/19/DPBPR tanggal 22 April 2004 perihal Pedoman Standar Penerapan Prinsip Mengenal Nasabah bagi Bank Perkreditan Rakyat.

Berdasarkan ketentuan di atas, bank diwajibkan untuk menerapkan prinsip mengenal nasabah dengan cara antara lain mengidentifikasi nasabah, pemantauan terhadap rekening dan transaksi nasabah, mengidentifikasi transaksi keuangan mencurigakan, dan lainnya, yang tersimpul dalam dokumentasi profil nasabah, yang minimal berisikan data identitas, pekerjaan/bidang usaha, jumlah penghasilan, rekening yang dimiliki, aktivitas transaksi normal dan tujuan pembukaan rekening nasabah. ${ }^{7}$ Serta membentuk unit kerja khusus dan/ atau menunjuk pejabat bank yang bertanggung jawab atas penerapan prinsip mengenal nasabah serta menerapkan prinsip mengenal nasabah yang berlaku di suatu negara bagi kantor cabang bank yang berada di luar negeri, sepanjang standar prinsip mengenal nasabahnya sama atau lebih ketat daripada yang diatur dalam Peraturan BI. Jika ketentuan setempat lebih longgar, maka yang wajib diterapkan adalah PBI KYC. Penerapan ini yang mengakibatkan pelanggaran ketentuan negara setempat wajib dilaporkan ke kantor pusat bank tersebut dan BI. ${ }^{8}$

Oleh karena itu pihak bank harus mengetahui karakter dan identitas dari nasabahnya karena dengan mengetahui karakter nasabahanya dengan baik maka bank dapat terhindar dari penyalahgunaan jasa oleh nasabahnya. Penyalahgunaan dalam hal ini berupa tindak pidana perbankan. Salah satu jenis tindak pidana perbankan yang rawan terjadi adalah pencucian uang (money laundering). ${ }^{9}$ Dalam hal ini diperlukan peranan dan kerjasama perbankan dalam membantu penegakkan hukum dalam menjalankan anti pencucian uang dan pencegahan pendanaan terorisme. Pelaksanaan program anti pencucian uang oleh perbankan diharapkan dapat memitigasi berbagai risiko yang mungkin timbul antara lain risiko hukum, risiko reputasi, risiko operasional dan risiko konsentrasi. Profil nasabah yang wajib dipelihara oleh bank sekurang-kurangnya memuat informasi yang meliputi antara lain yaitu: a. Pekerjaan atau bidang usaha b. Jumlah penghasilan c. Rekening lain yang dimiliki d. Aktivitas transaksi normal e. Tujuan pembukaan rekening Berdasarkan dokumen pendukung yang telah disampaikan oleh calon nasabah, Bank wajib melakukan identifikasi dan verifikasi

\footnotetext{
7 Marlina Kalangkahan, "Penerapan Prinsip Mengenal Nasabah Dalam Transaksi Perbankan Berdasarkan Undang-Undang Nomor 10 Tahun 1998", Lex Privatum, Vol. VII/No. 2/Feb/2019, Hlm 165-166.

8 Elisabeth Y Metekohy dan Ida Nurhayati, "Efektivitas Prinsip Mengenal Nasabah Pada Bank Sebagai Salah Satu Upaya Mencegah Tindak Pidana Pencucian Uang”, Jurnal Ekonomi Dan Bisnis, Vol 11, NO. 1, Juni 2012 hlm 26.

9 M. Rudi Setiawan, "Implementasi Prinsip Mengenal Nasabah Sebagai Upaya Pencegahan Tindak Pidana Pencucian Uang”, Journal Diversi, Volume 3, Nomor 2, September 2017, hlm 148.
} 
Volume 12, Nomor 2, April 2021

baik terhadap nasabah perorangan maupun perusahaan. ${ }^{10}$

Kewajiban pemantauan identitas, transaksi serta rekening nasabah (record keeping obligations) yang kemudian dilaporkan kepada Financial Intelegence Unit (PPATK) mewujudkan terciptanya database informasi yang dapat dipergunakan oleh FIU/PPATK dan penegak hukum untuk menelusuri proses terjadinya money laundering sehingga memudahkan penegak hukum untuk melakukan investigasi lebih lanjut. Baik dalam PBI KYC maupun dalam UU Tindak Pidana Pencucian Uang bank diwajibkan melaporkan Transaksi Keuangan Mencurigakan (suspicious transaction report) yaitu: transaksi keuangan yang mentimpang dari profil, karakteristik, atau kebiasaan pola transaksi nasabah; transaksi yang patut diduga untuk menghindari pelaporan; dan transaksi keuangan yang dilakukan atau batal dilakukan dengan menggunakan harta kekayaan yang diduga berasal dari hasil tindak pidana, kepada PPATK. Dengan ditetapkannya ketentuan ini maka petugas bank wajib memastikan bahwa pembukaan rekening oleh calon nasabah dilakukan setelah bank mempunyai keyakinan atas kredibilitas yang bersangkutan dan rekeningnya dipergunakan untuk kepentingan usahanya maupun keperluan pribadinya. ${ }^{11}$

Dalam rangka pemantauan terhadap rekening dan transaksi nasabah, bank harus melakukan verifikasi yang lebih ketat terhadap:

1. Calon nasabah yang berasal

2. dari negara yang diklasifikasikan sebagai high risk countries atau negara yang belum/ tidak menerpakan ketentuan prinsip menganl nasabah.

3. Bidang usaha yang potensial digunakan sebagai saran pencucian uang Calon nasabah yang mempunyai resiko tinggi, seperti pejabat pemerintah, politikus, pimpinan negara, pejabat pengadilan atau militer, dan pejabat eksekutif badan usaha milik pemerintah, anggota legislatif, dll. ${ }^{12}$

Bilamana perlu dilakukan kunjungan setempat (site visit) untuk meneliti apakah kondisi kegiatan usaha nasabah memang sesuai dengan volume usaha dan arus kas (cash flow) yang ada. Prosedur identifikasi nasabah dalam rangka penerapan prinsip mengenal nasabah tidak hanya secara prosedur pada umumnya dalam pembukaan rekening seperti yang tercantum dalam Pasal 4, 5, 6, Peraturan Bank Indonesia Nomor 3/10/PBI/2001tentang Penerapan Prinsip Mengenal Nasabah tetapi juga harus bisa menggali lebih dalam tentang nasabah itu sendiri, karena tidak dapat dimungkiri kecanggihan teknologi saat ini juga menunjang terjadinya tindak pidana pencucian uang dengan berbagai macam bentuk, sehingga bank juga

\footnotetext{
10 Leny Eka Novitiyaningsih, Krisnadi Nasution, "Prinsip Mengenal Nasabah Pada Bank Umum Dalam Mencegah Tindak Pidana Pencucian Uang”, Jurnal Hukum Bisnis Bonum Commune, Volume 2 Nomor 1 Februari 2019, hlm 60.

11 Yunus Husein. “Arti Penting Pelaksanaan Undang-Undang Anti Money Laundering Dan Prinsip Mengenal Nasabah Bagi Bank Dan Nasabah”, https://d1wqtxts1xzle7.cloudfront.net/35560143/30, di akses pada Tanggal 9 Maret 2021 Pukul 11:26 WIB, hlm 5.

12 M. Rudi Setiawan, "Implementasi Prinsip Mengenal Nasabah Sebagai Upaya Pencegahan Tindak Pidana Pencucian Uang”, Journal Diversi, Volume 3, Nomor 2, September 2017, hlm 150.
} 
Volume 12, Nomor 2, April 2021

harus bisa menganalisa lebih detail tentang karakteristik nasabah demi mengantisipasi atau mencegah munculnya celah yang bisa mengakibatkan terjadinya tindak pidana pencucian uang.

\section{Pedoman Standar Penerapan Prinsip Mengenal Nasabah}

Pedoman Standar Penerapan Prinsip Mengenal Nasabah Sebagai implementasi dari ketentuan PBI tentang Prinsip Mengenal Nasabah, Bank Indonesia telah mengeluarkan suatu pedoman sebagai acuan bank dalam menerapkan prinsip mengenal nasabah dalam setiap kegiatannya. Pedoman ini dikeluarkan berdasarkan Surat Edaran Bank Indonesia (SEBI) tanggal 13 Desember 2001 Nomor 3/29/DPNP tentang Pedoman Standar Penerapan Prinsip Mengenal Nasabah. Pedoman ini merupakan standar minimum yang wajib dipenuhi oleh bank dalam menyusun pedoman pelaksanaan penerapan prinsip mengenal nasabah. Pedoman ini disusun, dikarenakan ketentuan prinsip mengenal nasabah merupakan hal yang relatif baru bagi industri jasa keuangan, khususnya bank. Oleh karena itu, dibutuhkan persamaan persepsi dan pemahaman dari semua lembaga perbankan yang ada, baik dari pembuatan kebijakankebijakan tentang prinsip mengenal nasabah, maupun pelaksanaan prinsip itu sendiri.

Pedoman ini disusun banyak mengacu pada kebiasaan-kebiasaan internasional (international best practises), masukan dari perwakilan bank-bank yang ada di Indonesia, dan berbagai sumber lainnya. Adapun hal-hal penting yang ditentukan dalam pedoman standar ini adalah mengenai kebijakan umum, prosedur penerimaan dan identifikasi (procedures for customer acceptance and identification), pemantauan dan pelaporan (monitoring and reporting), dan pelatihan pegawai (employee training).

Oleh karena itu, Bank Indonesia berharap dengan adanya pedoman standar penerapan prinsip mengenal nasabah ini, setiap bank akan menerapkan prinsip mengenal nasabah sesuai dengan standar yang ditentukan oleh Bank Indonesia, sehingga hasil yang diinginkan dapat di capai.

\section{Sanksi Terhadap Bank yang Tidak Menerapkan Prinsip Menegenal Nasabah}

Berkenaan dengan pengenaan sanksi ini, Bank Indonesia telah mengeluarkan ketentuan mengenai sanksi terhadap bank yang tidak menerapkan prinsip mengenal nasabah dalam setiap kegiatannya, yaitu berdasarkan Surat Edaran Bank Indonesia Nomor 6/37/DPNP Perihal Penilaian dan Pengenaan Sanksi atas Penerapan Prinsip Mengenal Nasabah dan Kewajiban Lain Terkait dengan Undang-Undang Tindak Pidana Pencucian Uang. Sebelum Bank Indonesia memberikan sanksi, terlebih dahulu Bank Indonesia melakukan penilaian terhadap penerapan prinsip mengenal nasabah yang telah dilakukan oleh bank yang bersangkutan. Penilaian ini berkaitan dengan ketentuan manajemen risiko yang telah ditentukan dalam PBI tentang Prinsip Mengenal Nasabah. yang meliputi pengawasan oleh pengurus bank, pendelegasian wewenang, pemisahan tugas, sistem pengawasan interen, dan program pelatihan karyawan mengenai prinsip mengenal nasabah.

Berdasarkan hal inilah Bank Indonesia memberikan penilaian terhadap bank-bank yang 
Volume 12, Nomor 2, April 2021

telah menerapkan prinsip mengenal nasabah dalam setiap kegiatannya. Setelah dilakukannya penilaian-penilaian di atas, maka Bank Indonesia akan memberikan sanksi terhadap bankbank yang tidak menerapkan prinsip mengenal nasabah dengan baik dalam setiap kegiatannya. Sanksi yang akan diberikan oleh Bank Indonesia terhadap bank-bank dalam kategori berupa penurunan tingkat kesehatan bank yang bersangkutan, dan pemberhentian pengurus bank melalui mekanisme penilaian kelayakan dan kepatutan (fit and proper test). Bank Indonesia juga akan memberikan sanksi administratif dan teguran tertulis terhadap bank-bank yang melakukan pelanggaran ketentuan prinsip mengenal nasabah yang telah diatur dalam PBI, khususnya yang berkaitan dengan ketentuan pelaporan transaksi keuangan mencurigakan dan keterlambatan penyampaian pedoman prinsip mengenal nasabah oleh bank yang bersangkutan.

Bagi Bank yang lalai dalam melakukan tugasnya dalam rangka program kenal nasabah akan dikenakan sanksi administrasi sebagaimana dimaksud dalam Undang-undang Republik Indonesia Nomor 10 Tahun 1998 tentang Perbankan, selain itu apabila cukup bukti bahwa telah terjadi kejahatan money laundering, si pelakunya dapat diproses pidana sesuai aturan yang berlaku. ${ }^{13}$

Dengan adanya sanksi ini, diharapkan semua bank yang ada di Indonesia dapat menerapkan prinsip mengenal nasabah dengan sebaik-baiknya, agar terhindar dari risikorisiko yang timbul akibat transaksi yang dilakukan oleh bank itu sendiri Walaupun Bank Indonesia sudah mengeluarkan ketentuan mengenai sanksi atas pelanggaran prinsip mengenal nasabah, namun, tidak bisa dipungkiri masih ada bank yang tidak menerapkan prinsip ini dalam setiap kegiatannya. Hal ini dikarenakan ketentuan prinsip ini dianggap dapat merugikan bank dan mengurangi volume nasabah.

\section{Penerapan Prinsip Mengenal Nasabah Pada Bank Perkreditan Rakyat dalam Upaya Pencegahan Tindak Pidana Pencucian Uang dan Pencegahan Pendanaan Terorisme berdasarkan PBI Nomor 12/20/PBI/2010}

Berkembangnya industri Bank Perkreditan Rakyat yang disertai dengan perkembangan produk serta pelayanan terutama kepada para nasabahnya, yang dengan pemanfaatan berbasis teknologi informasi maka resiko terhadap Bank Prekreditan Rakyat dalam pencucian uang dan pendanaan teroris semakin tinggi. Ketentuan Bank Indonesia tentang penerapan prinsip mengenal nasabah (know your costumer principles) yang selama ini diterapkan dinilai perlu disesuaikan dengan mengacu pada standar internasional yang lebih komprehensif dalam mendukung upaya pencegahan tindak pidana pencucian uang dan pencegahan pendanaan terorisme. Penyesuaian pengaturan tersebut antara lain meliputi:

1. Penggunaan istilah Costumer Due Delegence dalam identifikasi, verifikasi, dan pemantauan nasabah

\footnotetext{
13 Alis Yulia, "Prinsip Mengenal Nasabah (Know Your Customer Principle) Oleh Penyedia Jasa Keuangan Di Bidang Pasar Modal”, Volume 7 No. 1- Maret 2019, hlm 36.
} 
Volume 12, Nomor 2, April 2021

2. Penggunaan istilah enhanced due diligence dalam pelaksanaan CDD yang lebih mendalam dalam hal BPR berhubungan dengan nasabah yang berisiko tinggi termasuk politically exposed person

3. Pengaturan mengenai pencegahan pendanaan terorisme, dan

4. Pengaturan mengenai transfer dana atau pemindahan dana

Ketentuan tentang penerapan prinsip mengenal nasabah (know your costumer principles) bagi Bank Perkreditan Rakyat yang berlaku selama ini perlu untuk disempurnakan dengan mengacu pada prinsip-prinsip umum yang berlaku secara internasional dalam mendukung upaya pencegahan tindak pidana pencucian uang dan pencegahan pendanaan terorisme.

Prinsip mengenal nasabah bertujuan untuk mengimplementasikan Undang-Undang Nomor 15 Tahun 2002 tentang Tindak Pidana Pencucian Uang, sebagaimana telah diubah dengan Undang-Undang Nomor 25 Tahun 2003, serta mengimplementasikan PBI Nomor 3/10/PBI/2001 dan perubahan Nomor 3/23/PBI/2001. Ketentuan Bank Indonesia yang mengacu kepada ketentuan mengenai penerapan prinsip mengenal nasabah, telah digantikan dengan Undang-Undang Nomor 12/20/PBI/2010. Dan penyempurnaan terus dilakukan terhadap Undang-Undang dan PBI yang berkaitan dengan pencucian uang dan prinsip mengenal nasabah. Hal ini dimaksudkan agar Indonesia terhindar dari tempat pencucian uang dan tetap termaksud negara dengan category cooperative country, sehingga Indonesia dapat dipercaya dan terus dapat melakukan kegiatan transaksi keuangan dengan Dunia internasional.

Pelaksanaan penerapan program anti pencucian uang diawali dengan membuat Pedoman dan Kebijakan Standar Penerapan Prinsip Mengenal Nasabah sebagai syarat bagi Bank Perkreditan Rakyat dalam mendukung program tersebut. Pedoman Standar Penerapan Prinsip Mengenal Nasabah yang dibuat oleh Bank indonesia setidaknya memuat kebijakan tentang penerimaan dan identifikasi calon nasabah, kebijakan tentang pemantauan rekening dan transaksi nasabah, dan kebijakan manajemen risiko. Dan berdasarkan peraturan disebutkan pula bahwa setiap Bank wajib untuk membentuk unit kerja khusus yang melaksanakan program Anti Pencucian Uang dan Pencegahan Pendanaan Teroris, yaitu Unit Kerja Penerapan Prinsip Mengenal Nasabah (UKPN). Dan dalam menjalankan tugasnya, unit ini melapor dan bertanggung jawab langsung kepada Direktur Kepatuhan. Selain itu, UKPN mengatur dan mengkoordinasikan satuan kerja operasional dibawahnya yang meliputi Kantor Cabang termasuk kantor-kantor yang berada dibawah supervisinya serta satuan kerja operasional di Kantor Pusat, dalam menerapkan program tersebut diatas karena satuan kerja operasional itu merupakan satuan kerja terdepan yang memagari Bank dari upaya pencucian uang dan pendanaan terorisme. Satuan kerja operasional harus memastikan bahwa pengawasan internal berfungsi dengan baik, tepat dan beroperasi secara efektif serta memastikan bahwa seluruh karyawan di satuan kerja operasional telah diberi pelatihan yang memadai sehingga setiap karyawan memiliki pemahaman yang sama perihal pencucian uang 
Volume 12, Nomor 2, April 2021

dan pendanaan terorisme. Berikut ini merupakan tahapan dalam kegiatan Bank yang dilakukan untuk mencegah pencucian uang, yaitu:

Dalam menerapkan program APU dan PPT, BPR dan BPRS wajib memiliki kebijakan dan prosedur tertulis yang paling kurang mencakup hal-hal sebagai berikut:

1. Pelaksanaan CDD, yang terdiri dari:

a. permintaan informasi dan dokumen;

b. verifikasi dokumen; dan

c. pengkinian dan pemantauan.

2. Penatausahaan dokumen;

3. Pemindahan dana;

4. Penutupan hubungan dan penolakan transaksi;

5. Ketentuan mengenai Beneficial Owner;

6. Ketentuan mengenai area berisiko tinggi dan PEP;

7. Pelaksanaan CDD yang lebih sederhana; dan

8. Pelaksanaan CDD oleh pihak ketiga.

Dalam peraturan bank indonesia, BPR diwajibkan untuk menerapkan prinsip mengenal nasabah. Kewajiban Bank Perkreditan Rakyat untuk menerapkan prinsip mengenal nasabah (Know Your Customer Principles) dalam setiap transaksi yang dilakukannya tentu saja berkaitan dengan nasabah itu sendiri. Hal ini dikarenakan bahwa prinsip mengenal nasabah mengharuskan pihak bank untuk lebih mengenal profil nasabahnya dan bahkan harus meminta informasi yang sangat pribadi dari nasabah yang bersangkutan, Prinsip mengenal nasabah akan terlaksana apabila nasabah bekerjasama dengan pihak bank yang bersangkutan, dengan kata lain prinsip mengenal nasabah ini harus dilaksanakan secara bersama-sama antara bank dengan nasabahnya. Oleh karena itu, pihak BPR harus mensosialisasikan dengan sangat baik tentang pentingnya prinsip mengenal nasabah, agar nasabah tidak terganggu dengan adanya ketentuan ini.

\section{PENUTUP}

Penerapan prinsip mengenal nasabah (know your costumer principles) bagi Bank Perkreditan Rakyat yang berlaku selama ini perlu untuk disempurnakan dengan mengacu pada prinsipprinsip umum yang berlaku secara internasional dalam mendukung upaya pencegahan tindak pidana pencucian uang dan pencegahan pendanaan terorisme. Prinsip mengenal nasabah bertujuan untuk mengimplementasikan undang-undang yang berlaku saat ini. Pedoman dan Kebijakan Standar Penerapan Prinsip Mengenal Nasabah sebagai syarat bagi Bank Perkreditan Rakyat dalam mendukung program tersebut. Pedoman Standar Penerapan Prinsip Mengenal Nasabah yang dibuat oleh Bank Indonesia setidaknya memuat Kebijakan tentang penerimaan dan identifikasi calon nasabah, kebijakan tentang pemantauan rekening dan transaksi nasabah, dan kebijakan manajemen risiko. Dan berdasarkan peraturan disebutkan pula bahwa setiap Bank wajib untuk membentuk unit kerja khusus yang melaksanakan 
Volume 12, Nomor 2, April 2021

program Anti Pencucian Uang dan Pencegahan Pendanaan Teroris, yaitu Unit Kerja Penerapan Prinsip Mengenal Nasabah (UKPN) terhadap Bank Pekreditan Rakyat.

Untuk nasabah yang belum memahami pentingnya data atau informasi yang terkait dengan keuangan pribadi untuk tidak memberikan data yang terkesan asal-asalan demi keamanan antara pihak nasabah dan perbankan. Dan perlu adanya peran serta pemerintah, pihak bank, dan pihak yang terkait untuk melakukan sosialisasi untuk member informasi dan pemahaman terhadap nasabah bahwa nasabah tidak perlu takut apabila kekayaan yang dimilikinya, terbongkar atau data pribadi tidak terbongkar. Serta pemahanan ketentuan yang terkait tindak pidana pencucian uang oleh semua petugas Bank sangat penting sehingga perlu diadakannya pelatihan kepada petugas Bank karena mereka adalah penyaring terdepan ketika Bank melakukan hubungan usaha dengan calon nasabah / walk-in customer.

\section{DAFTAR PUSTAKA}

\section{Buku}

Djaslim Saladin, Dasar-Dasar Manajemen Pemasaran Bank, Jakarta: CV Rajawali, 1994. Djoni S. Gazali dan Rachman Usman, Hukum Perbankan, Jakarta: Sinar Grafika, 2012. Djumhana Muhammad, Hukum Perbankan di Indonesia, Bandung: PT Aditya Bakti, 2006. Komarudin, Kamus Perbankan. Jakarta: Rajawali. 1989.

Pramono Nindyo, Bunga Rampai Hukum Bisnis Aktual, Bandung: Citra Aditya Bakti, 2006.

\section{Jurnal}

Alis Yulia, "Prinsip Mengenal Nasabah (Know Your Customer Principle) Oleh Penyedia Jasa Keuangan Di Bidang Pasar Modal”, Volume 7 No. 1- Maret 2019.

Asep Rozali, "Prinsip Mengenal Nasabah (Know Your Customer Principle) Dalam Praktik Perbankan", Jurnal Wawasan Hukum, Vol. 24 No. 01 Februari 2011.

Elisabeth Y Metekohy dan Ida Nurhayati, "Efektivitas Prinsip Mengenal Nasabah Pada Bank Sebagai Salah Satu Upaya Mencegah Tindak Pidana Pencucian Uang”, Jurnal Ekonomi Dan Bisnis, Vol 11, No. 1, Juni 2012.

M. Rudi Setiawan, "Implementasi Prinsip Mengenal Nasabah Sebagai Upaya Pencegahan Tindak Pidana Pencucian Uang”, Journal Diversi, Volume 3, Nomor 2, September 2017.

Leny Eka Novitiyaningsih, Krisnadi Nasution, "Prinsip Mengenal Nasabah Pada Bank Umum Dalam Mencegah Tindak Pidana Pencucian Uang", Jurnal Hukum Bisnis Bonum Commune, Volume 2 Nomor 1 Februari 2019.

Marlina Kalangkahan, "Penerapan Prinsip Mengenal Nasabah Dalam Transaksi Perbankan Berdasarkan Undang-Undang Nomor 10 Tahun 1998", Lex Privatum, Vol. VII/No. 2/Feb/2019.

Yunus Husein. “Arti Penting Pelaksanaan Undang-Undang Anti Money Laundering Dan Prinsip Mengenal Nasabah Bagi Bank Dan Nasabah", 
Volume 12, Nomor 2, April 2021

https://d1wqtxts1xzle7.cloudfront.net/35560143/30, di akses pada Tanggal 9 Maret 2021 Pukul 11:26 WIB.

\section{Peraturan Perundamg-undangan}

Undang-Undang Nomor 10 Tahun 1998 tentang Perubahan atas Undang-Undang Nomor 7 Tahun 1992 tentang Perbankan, LN tahun 1992 Nomor 3472.

Peraturan Otoritas Jasa Keuangan Nomor 22/POJK.04/2014 tentang Prinsip Mengenal Nasabah oleh Penyedia Jasa Keuangan di Sektor Pasar Modal.

Peraturan Bank Indonesia Nomor 14 Tahun 2012 tentang Penerapan Program Anti Pencucian Uang dan Pencegahan Pendanaan Terorisme Bagi Bank Umum.

Peraturan Bank Indonesia Nomor: 12/ 20 /PBI/2010 tentang Penerapan Program Anti Pencucian Uang dan Pencegahan Pendanaan Terorisme bagi Bank Perkreditan Rakyat dan Bank Pembiayaan Rakyat Syariah.

Peraturan Bank Indonesia Nomor 5 Tahun 2003 tentang Penerapan Prinsip Mengenal Nasabah bagi Bank Perkreditan Rakyat. TLN RI tahun 2003 Nomor 4328.

Peraturan Bank Indonesia Nomor 3/10/PBI/2001 tentang Penerapan Prinsip Mengenal Nasabah. 